\title{
Asymmetric aldol reaction using boron enolates
}

\author{
Katie M Cergol $^{1}$ \& Mark J Coster ${ }^{2}$
}

${ }^{1}$ School of Chemistry, The University of Sydney, NSW 2006, Australia. ${ }^{2}$ Eskitis Institute for Cell and Molecular Therapies, Griffith University, Nathan, Queensland 4111, Australia. Correspondence should be addressed to M.J.C. (Tel.: +61-7-3735-6037; Fax: +61-7-3735-6001; Email: m.coster@griffith.edu.au).

The protocol for the preparation of boron enolates and their subsequent reaction with aldehydes is described, providing convenient access to $\beta$-hydroxy ketones in good yields and with high stereoselectivities. The reaction consists of three steps; firstly the ketone is rapidly converted to the corresponding boron enolate, by exposure to a chlorodialkylborane and tertiary amine base, which is then reacted in situ with the aldehyde. Finally, oxidative workup of the resultant boron aldolate provides aldol adduct. The reaction procedure requires approximately $28 \mathrm{~h}$ to complete over a two day period, consisting of $5 \mathrm{~h}$ to set up the reaction, whereupon the reaction mixture is left at $-20{ }^{\circ} \mathrm{C}$ overnight (16 h), followed by $7 \mathrm{~h}$ for workup and purification.

\section{INTRODUCTION}

The directed aldol reaction of boron enolates and aldehydes has often been employed in stereoselective organic synthesis, including the syntheses of several complex natural products, owing in large part to the high levels of chemo-, regio-, diastereo and enantioselectivity that can be achieved. ${ }^{1-3}$ One of the most universal stereochemical features of the boron-mediated aldol reaction is the transfer of enolate geometry to aldol product relative stereochemistry with high fidelity, where (Z)-boron enolates generally give syn aldol products and $(E)$-boron enolates afford anti aldol adducts. $^{2}$ High levels of absolute control in the creation of new stereogenic centres can be achieved by using certain chiral ketone and/or aldehyde substrates, or through the use of chiral ligands on boron. The use of two or more "matched"4 chiral components in these aldol reactions can result in exceptionally high levels of diastereoselectivity.

The generally predictable stereochemical outcomes observed in the aldol reaction between boron enolates and aldehydes result from kinetic control, and have been very effectively rationalised computationally with transition state models involving highly-ordered chair- or boat-like transition states. ${ }^{5,6}$ An extension of this protocol to the reaction of boron enolates with certain ketones, particularly cyclohexanones, ${ }^{7}$ pushes the boundaries of reactivity for this reaction manifold, and has recently been shown to be a reversible process, in sharp contrast to the situation with aldehyde reaction partners. ${ }^{8}$

A typical procedure for carrying out a boron-mediated aldol reaction begins with treatment of the ketone starting material with a Lewis acidic boron reagent, $\mathrm{L}_{2} \mathrm{BX}(\mathrm{X}=\mathrm{Cl}, \mathrm{Br}, \mathrm{OTf})$, and a tertiary amine base, thereby forming the boron enolate 1, in situ (Fig. 1). The most common achiral boron reagents for this purpose are $B$-chlorodicyclohexylborane ${ }^{9}\left(\mathrm{Chx}_{2} \mathrm{BCl}\right)$ or di- $n$-butylboron triflate ${ }^{10}$ $\left(n-\mathrm{Bu}_{2} \mathrm{BOTf}\right)$, whereas both enantiomers of $B$-chlorodiisopinocampheylborane ${ }^{11,12}$ (Ipc $\left._{2} \mathrm{BCl}\right)$ have frequently been used in aldol reactions where a chiral boron enolate is necessary for enantioselectivity or desirable in order to enhance or overturn inherent facial bias of the reaction substrates. All boron Lewis acids of this type react rapidly with water via B-X bond heterolysis, and therefore great care must be taken to avoid contact of these reagents and their solutions with atmospheric moisture. Additionally, many boranes undergo cleavage of B-C bonds when exposed to oxygen, and therefore atmospheric oxygen should also be excluded. As such, boron-mediated aldol reactions are performed using anhydrous, anaerobic conditions, under an inert atmosphere of nitrogen or argon.

The boron enolate solution is then treated with the aldehyde, whereby an ate complex $\mathbf{2}$ is formed, facilitating bond reorganization to afford the boron aldolate 3. Typically, an oxidative hydrolytic workup, employing $\mathrm{H}_{2} \mathrm{O}_{2}$, is then performed to liberate the aldol adduct 4 , which also produces two 
equivalents of the alcohol corresponding to the alkyl ligands on boron, per equivalent of boron reagent used. When $\mathrm{Chx}_{2} \mathrm{BCl}$ is used, the cyclohexanol by-product can be removed under reduced pressure, owing to its volatility, whereas the use of $\mathrm{Ipc}_{2} \mathrm{BCl}$ results in formation of isopinocampheol $(\mathrm{IpcOH})$, requiring chromatographic separation from the aldol adduct. Where a product is particularly sensitive toward oxidants, the hydrolytic step can be achieved via a non-oxidative workup, such as exposure of the boron aldolate solution to silica gel. ${ }^{13}$

As an example of the asymmetric aldol reaction using boron enolates, we report the procedure for a matched aldol reaction of chiral ketone 5 , and chiral aldehyde $\mathbf{6}$, under (-)-Ipc $2 \mathrm{BCl}$ mediation, via boron enolate 7 (Fig. 2) ${ }^{14-17}$ This process is a key step in a stereocontrolled total synthesis of the potently cytotoxic marine natural product spongistatin 1 altohyrtin $\mathrm{A},{ }^{13-20}$ and exploits triple asymmetric induction ${ }^{4}$ to obtain the desired aldol adduct 8 in $78 \%$ yield, with exceptional diastereocontrol ( $>97: 3 d r$ ). It should be noted that boron-mediated aldol reactions with other substrates, using different boron Lewis acids, can be performed using analogous procedures, however, the reaction rates for each step may vary considerably. Hence, each individual reaction needs to be monitored by the most appropriate analytical techniques, and reaction temperatures may need to be modified, to ensure each step reaches completion before the next is undertaken.

\section{MATERIALS}

\section{REAGENTS}

(-)-B-Chlorodiisopinocampheylborane [(-)-Ipc ${ }_{2} \mathrm{BCl}$; (-)-DIP-Chloride ${ }^{\mathrm{TM}}$; Sigma-Aldrich, cat. no. 317020]

Triethylamine (see REAGENT SETUP)

Diethyl ether (see REAGENT SETUP)

pH 7 buffer solution (Buffer, Hydrion ${ }^{\mathrm{TM}}$, dry, pH $7.00 \pm$ 0.02; Sigma-Aldrich, cat. no. 239089;

contains sodium hydrogenphosphate and potassium dihydrogen phosphate)

Methanol

30\% Aqueous hydrogen peroxide solution

Saturated sodium bicarbonate solution

Brine

Sodium sulfate, anhydrous

\section{EQUIPMENT}

Inert atmosphere (dry argon or nitrogen) glovebox (can be substituted with a glovebag)

Round-bottom flasks or Schlenk glassware

Teflon-coated magnetic stir bar (small)

Heat gun

Conical flasks

Dual nitrogen-vacuum or argon-vacuum manifold

Argon-filled balloon attached via tubing to an 18 gauge needle

Rotary evaporator

Magnetic stirrer or hotplate/stirrer

Gas-tight syringes and microsyringes, with luer lock fittings

Spatula

Stainless steel cannulae (18 - 21 gauge)

Luer lock needles (18 - 21 gauge)

Ice

Separatory funnels

Rubber septa

Shallow Dewar vessel

Dry ice

Acetone

Parafilm 
100 mL Beaker

Laboratory freezer or chemical cold-room $\left(-20^{\circ} \mathrm{C}\right)$

Glass pipette and pipette teats

Glass funnel and filter paper or sintered glass funnel

Columns for chromatography

Silica gel (230-400 mesh)

Aluminium-backed silica gel $\mathrm{F}_{254}$ thin-layer chromatography plates

Cerium Molybdate Stain (Hanessian's Stain or “Goofy's dip”) - prepared by the dropwise addition of sulfuric acid $(2.5 \mathrm{~mL})$ to a solution of phosphomolybdic acid (2.5 g) and cerium(IV) sulfate (0.75

g) in water (48 mL).

${ }^{1} \mathrm{H}$ and ${ }^{13} \mathrm{C}$ NMR spectrometer

\section{REAGENT SETUP}

Diethyl ether Dried by distillation from sodium-benzophenone.

Triethylamine Dried by distillation from powdered calcium hydride.

\section{PROCEDURE}

\section{Synthesis of the boron enolate. Time: $3 \mathrm{~h}$}

1 Fit a $25 \mathrm{~mL}$ round-bottom flask containing a Teflon-coated magnetic stir bar with a rubber septum and connect the flask to a vacuum line.

2 Under vacuum, heat the flask with a heat gun for 2 min. Allow the flask to cool down to room temperature and then fill the flask with argon or nitrogen via the double manifold.

3 Remove the argon or nitrogen inlet and place the flask in a glovebox or glovebag, along with a spatula and the (-)-Ipc $\mathrm{IBCl}_{2} \mathrm{~B}$. After purging the glovebox with argon or nitrogen, remove the septum from the flask and weigh in (-)- $\mathrm{Ipc}_{2} \mathrm{BCl}$ (95 $\mathrm{mg}, 0.296 \mathrm{mmol}, 1.4$ equiv.) via spatula.

CAUTION All $\mathrm{R}_{2} \mathrm{BX}$ reagents used in the formation of boron enolates are strong Lewis acids and react with water to produce strong protic acids, HX. Spatulas or syringes that come into contact with these reagents should be carefully washed with diethyl ether into a beaker, and the ether washings neutralised with aqueous sodium bicarbonate solution prior to disposal of the waste.

4 Replace the septum onto the flask, remove from the glovebox and place under vacuum for 30 mins to remove traces of $\mathrm{HCl}$. If using other boron Lewis acids that are liquids, eg. chlorodicyclohexylborane, Steps 3 and 4 can be avoided, and the liquid boron reagent added to the reaction flask directly via gas-tight syringe.

$5 \quad$ Fill the flask with argon or nitrogen, then add diethyl ether (3 mL) via gas-tight syringe.

6 Using a magnetic stirrer, stir the mixture until the boron reagent has completely dissolved $(<$ 5 mins).

$7 \quad$ To make a $-78{ }^{\circ} \mathrm{C}$ cooling bath, add dry ice to a shallow dewar vessel, until the dry ice level is at, or just below, the rim of the vessel. Slowly add acetone until the dry ice is covered. There should be visible dry ice remaining in the vessel.

CAUTION Dry ice should be handled with tongs or insulated gloves only. Contact with skin can cause serious injury. 
8 Cool the flask containing the $(-)-\mathrm{Ipc}_{2} \mathrm{BCl}$ solution in the $-78{ }^{\circ} \mathrm{C}$ cooling bath, then add triethylamine (50 $\mu \mathrm{L}, 0.359 \mathrm{mmol}, 1.7$ equiv.) via microsyringe.

CRITICAL STEP The success of this step depends on the absence of moisture in the reagents and solvent. A significant white precipitate of triethylamine hydrochloride at this point would indicate that one of the reagents, or the diethyl ether is not anhydrous. In such a case, the reaction should be abandoned and started again using new or re-purified reagents and solvent.

$9 \quad$ To a separate $10 \mathrm{~mL}$ round-bottom flask containing ketone 5 (69.6 mg, $0.212 \mathrm{mmol}, 1.0$ equiv.), fit a rubber septum, and place under an atmosphere of argon by inserting an argonfilled balloon fitted with a needle, through the septum. Purge the flask with argon from the balloon by placing a vent needle through the septum, and allowing argon to flow through the flask for 10 seconds before removing the vent needle. When using non-volatile ketones, this step may also be achieved by placing the flask under vacuum, then refilling with argon.

10 To ketone 5, add diethyl ether (1 mL) via syringe. Gently swirl the contents of the flask, to dissolve the ketone.

11 Insert one end of a double-tipped cannula into the flask containing the $\mathrm{Ipc}_{2} \mathrm{BCl} /$ triethylamine solution, and the other end into the flask containing ketone 5. Lower one end of the cannula, such that the tip is below the level of the solution containing the ketone. Add the ketone solution dropwise to the flask containing the $\mathrm{Ipc}_{2} \mathrm{BCl} /$ triethylamine solution. The pressure exerted by the Ar-filled balloon will be greater than the nitrogen pressure from the oil-bubbler vented double manifold, and this pressure difference will force the ketone solution through the cannula and into the $\mathrm{Ipc}_{2} \mathrm{BCl} /$ triethylamine solution.

CRITICAL STEP The success of this step is dependent on avoiding the introduction of air into the reaction flask. Moisture in the air may cause hydrolysis of the boron reagent and/or the boron enolate formed, leading to a decreased yield of aldol product.

12 Rinse the last traces of ketone into the reaction flask by lifting the ketone end of the cannula to the neck space of this flask, while still remaining inserted through the septum. Add diethyl ether $(0.5 \mathrm{~mL})$ to the $10 \mathrm{~mL}$ ketone-containing flask, swirl, then lower the cannula end to transfer this first wash to the receiving reaction flask.

13 Repeat step 12 once more with a further portion of diethyl ether $(0.5 \mathrm{~mL})$. Remove the cannula from both reaction flasks.

14 Remove the reaction flask from the $-78{ }^{\circ} \mathrm{C}$ cooling bath and place in an ice-water bath (ca. $0{ }^{\circ} \mathrm{C}$ ). For alternative procedures using other ketones and/or reagents, this step may be completed at a lower temperature or in less time. In general, unhindered (particularly methyl) ketones enolise rapidly at $-78^{\circ} \mathrm{C}$, while the use of more reactive boron Lewis acids also typically enables the use of lower temperatures or shorter enolisation times.

15 Stir at $0{ }^{\circ} \mathrm{C}$ for $1 \mathrm{~h}$. During this period, a white precipitate of triethylamine hydrochloride will develop, thereby providing a visual indicator of boron enolate formation (Fig. 3). Depending on the boron reagent and tertiary amine employed in this step, this white precipitate may not be observed, eg. conjugate acids of $\mathrm{N}, \mathrm{N}$-diisopropylethylamine are generally more soluble in diethyl ether. 


\section{Aldol reaction. Time: $18 \mathrm{~h}$}

16 Place the reaction flask into the dry ice-acetone cooling bath. Add additional dry ice to the bath if no visible dry ice remains.

17 To a separate $10 \mathrm{~mL}$ round-bottom flask containing aldehyde 6 (93.0 mg, $0.275 \mathrm{mmol}, 1.3$ equiv.), fit a rubber septum, and purge the flask with argon for 10 seconds from a balloon, as in step 9.

18 To aldehyde 6, add diethyl ether (1 mL) via syringe. Gently swirl the contents of the flask to dissolve the aldehyde.

19 Using an analogous procedure to steps 11-13, cannulate the aldehyde solution into the reaction flask, washing the aldehyde flask with further diethyl ether $(2 \times 0.5 \mathrm{~mL})$.

20 Stir the reaction mixture at $-78{ }^{\circ} \mathrm{C}$ for 90 mins.

21 Remove the inlet needle from the reaction flask septum, and wrap the septum in Parafilm, such that a tight seal is formed over the punctured part of the septum and at the interface between flask and septum.

22 Place the reaction flask into a $100 \mathrm{~mL}$ beaker (Fig. 4).

23 Place the beaker containing the reaction flask into a $-20{ }^{\circ} \mathrm{C}$ freezer or cold-room. Keep the reaction at $-20{ }^{\circ} \mathrm{C}$ for $16 \mathrm{~h}$. The temperature and duration of this step may need to be modified depending on the aldehyde used in Steps 17-19. Reactions between particularly unhindered ketone and aldehyde substrates are usually rapid, and often complete within $1 \mathrm{~h}$ at $-78{ }^{\circ} \mathrm{C}$. However, allowing these reactions to stand at $-20{ }^{\circ} \mathrm{C}$ overnight is not usually deleterious, and as such we recommend the above protocol for all aldol reactions between ketones and aldehydes. Ketone-ketone aldol reactions are less facile, and generally require $16 \mathrm{~h}$ at $0{ }^{\circ} \mathrm{C}$ to reach completion. ${ }^{7,8}$

\section{Oxidative workup. Time: $2 \mathrm{~h}$}

24 To a $25 \mathrm{~mL}$ conical flask, add $\mathrm{pH} 7$ buffer solution $(4 \mathrm{~mL})$, methanol $(2 \mathrm{~mL})$ and $30 \%$ aqueous hydrogen peroxide $(2 \mathrm{~mL})$ and mix by swirling.

25 Remove the reaction flask from the freezer or cold-room, place the flask in an ice-water bath on a magnetic stirrer and commence stirring.

26 Remove the septum from the reaction flask and add the buffered aqueous methanolhydrogen peroxide solution dropwise to the stirred reaction flask via glass pipette.

27 Remove the reaction flask from the cooling bath and stir the mixture vigorously for $1 \mathrm{~h}$ at room temperature.

28 Transfer the contents of the reaction vessel to a separatory funnel and rinse the flask with water $(10 \mathrm{~mL})$ and diethyl ether $(10 \mathrm{~mL})$.

29 Separate the organic and aqueous layers and extract the aqueous layer with further diethyl ether $(3 \times 5 \mathrm{~mL})$. 
30 Wash the combined organic extracts with saturated sodium bicarbonate solution $(1 \times 10 \mathrm{~mL})$ and brine $(1 \times 10 \mathrm{~mL})$, then dry the organic layer over anhydrous sodium sulfate (approx. 2 g) in a $50 \mathrm{~mL}$ conical flask, by swirling the contents of the flask for $c a .1$ minute.

31 Filter the inorganic materials under gravity through a fluted filter paper on a glass funnel, or through a sintered glass funnel with vacuum, into a $100 \mathrm{~mL}$ round-bottom flask, washing the filter paper or sintered glass funnel with diethyl ether $(2 \times 5 \mathrm{~mL})$.

32 Remove the volatiles by rotary evaporation (water bath $\mathrm{T} \leq 30^{\circ} \mathrm{C}$ ), to give a colorless oil.

\section{Purification. Time: $\sim 5 \mathrm{~h}$}

33 Purify the desired product away from the majority of the isopinocampheol (IpcOH) contaminant by silica gel flash column chromatography $(2.5 \mathrm{~cm}$ internal diameter x $15 \mathrm{~cm}$ silica height) using 20:80 diethyl ether-dichloromethane as eluent. This eluent has been found to be uniquely effective for the separation of the IpcOH from the desired product. Other aldol reactions may not require the use of this eluent and may be performed solely using more user-friendly eluents, eg. ethyl acetate-hexanes. Collect all fractions containing the desired product $\left(R_{f}=0.72\right.$, 20:80 diethyl ether-dichloromethane), which will elute in the very early fractions, together with recovered aldehyde and minor byproducts, before the IpcOH $\left(R_{f}=0.43,20: 80\right.$ diethyl ether-dichloromethane) elutes. The fractions can be visualized on Merck pre-coated silica gel plates with $\mathrm{F}_{254}$ indicator, using UV light (256 $\mathrm{nm}$ ), followed by staining with cerium molybdate stain (Goofy's dip) and heating with a heat gun until coloration develops. Concentrate the combined aldol product containing fractions by rotary evaporation.

34 Purify the desired product by silica gel flash column chromatography $(2.2 \mathrm{~cm}$ internal diameter x $12 \mathrm{~cm}$ silica height) using 20:80 ethyl acetate-hexanes as eluent. The desired product $\left(R_{f}=0.48,30: 70\right.$ ethyl acetate-hexanes $)$ will elute after the excess aldehyde and some minor byproducts.

35 Obtain a 78\% yield of a colorless oil.

\section{TIMING}

Steps 1-4: $1 \mathrm{~h}$

Steps 5-15: $2 \mathrm{~h}$

Steps 16-23: $18 \mathrm{~h}$

Steps 24-32: $2 \mathrm{~h}$

Steps 33-35: $5 \mathrm{~h}$

\section{TROUBLESHOOTING}

Troubleshooting advice can be found in Table $\mathbf{1}$.

TABLE 1 Troubleshooting table.

\begin{tabular}{|l|l|l|l|}
\hline Step & Problem & Possible reason & Solution \\
\hline 3 & $\begin{array}{l}\text { Ipc } 2 \mathrm{BCl} \text { is a syrupy } \\
\text { liquid }\end{array}$ & Reagent is impure & $\begin{array}{l}\text { Pure } \mathrm{Ipc}_{2} \mathrm{BCl} \text { is a solid at room } \\
\text { temperature. An oily appearance indicates } \\
\text { impurities, most commonly due to } \\
\text { reaction with adventitious moisture. } \\
\text { Repeat reaction with fresh reagent. }\end{array}$ \\
\hline 4 & $\begin{array}{l}\text { Ipc } \mathrm{BCl} \text { appears to } \\
\text { fume or turns into a } \\
\text { syrupy liquid in the }\end{array}$ & $\begin{array}{l}\text { Leak in the septum or } \\
\text { vacuum line }\end{array}$ & $\begin{array}{l}\text { Check vacuum line for leaks. Repeat } \\
\text { procedure with fresh reagent and a new } \\
\text { septum. }\end{array}$ \\
\hline
\end{tabular}




\begin{tabular}{|c|c|c|c|}
\hline & reaction flask & & \\
\hline 8 & Precipitate formed & $\begin{array}{l}\text { Wet reagents or } \\
\text { solvent }\end{array}$ & $\begin{array}{l}\text { Repeat reaction with fresh reagents and } \\
\text { solvent, ensuring all are anhydrous. }\end{array}$ \\
\hline 15 & No precipitate formed & $\begin{array}{l}\text { Enolate has not been } \\
\text { formed }\end{array}$ & $\begin{array}{l}\text { Check that all correct reagents have been } \\
\text { used, and diethyl ether has been used as } \\
\text { solvent. If a mistake has been made, repeat } \\
\text { with correct reagents and solvent. If using } \\
\text { conditions other than } \mathrm{L}_{2} \mathrm{BCl} / \mathrm{Et}_{3} \mathrm{~N} \text { in } \\
\text { diethyl ether, a precipitate may not form. }\end{array}$ \\
\hline $33-34$ & $\begin{array}{l}\text { Product is not pure } \\
\text { after chromatography }\end{array}$ & $\begin{array}{lr}\text { Product } & \text { and } \\
\text { byproduct(s), } & \text { eg. } \\
\text { IpcOH, co-elute } & \end{array}$ & $\begin{array}{l}\text { Trial alternative eluent mixtures by TLC } \\
\text { and repeat chromatography. Alternatively, } \\
\text { HPLC may be required, or the mixture } \\
\text { may be telescoped through to the next } \\
\text { reaction in a synthetic sequence. }\end{array}$ \\
\hline
\end{tabular}

\section{ANTICIPATED RESULTS \\ Analytical data \\ Aldol adduct 8.}

Yield 78\%;

colourless oil;

$[\alpha]_{\mathrm{D}}-2.5\left(c=1.69\right.$ in $\mathrm{CHCl}_{3}$ at $\left.20^{\circ} \mathrm{C}\right)$;

TLC (ethyl acetate:hexanes 30:70) $R_{f}=0.48$;

${ }^{1} \mathrm{H}$ NMR (500 MHz, $\left.\mathrm{CDCl}_{3}\right) \delta 7.24(2 \mathrm{H}, \mathrm{d}, J=8.6 \mathrm{~Hz}), 6.87(2 \mathrm{H}, \mathrm{d}, J=8.6 \mathrm{~Hz}), 4.77(1 \mathrm{H}, \mathrm{d}, J=$ $1.4 \mathrm{~Hz}), 4.72(1 \mathrm{H}$, br s), $4.44(2 \mathrm{H}, \mathrm{s}), 4.23(1 \mathrm{H}, \mathrm{m}), 4.07(1 \mathrm{H}, \mathrm{m}), 3.97(1 \mathrm{H}, \mathrm{m}), 3.87(1 \mathrm{H}, \mathrm{m}), 3.80$ (3H, s), $3.52(1 \mathrm{H}, \mathrm{d}, J=2.2 \mathrm{~Hz}), 3.41(1 \mathrm{H}, \mathrm{dd}, J=9.7,5.1 \mathrm{~Hz}), 3.37(1 \mathrm{H}, \mathrm{dd}, J=9.7,5.1 \mathrm{~Hz}), 3.28$ (3H, s), 2.72 (1H, dd, $J=15.8,6.5 \mathrm{~Hz}), 2.60$ (1H, dd, $J=16.7,7.9 \mathrm{~Hz}), 2.53$ (1H, dd, $J=16.7,4.3$ Hz), $2.48(1 \mathrm{H}, \mathrm{dd}, J=15.8,5.5 \mathrm{~Hz}), 2.30(1 \mathrm{H}, \mathrm{dd}, J=13.6,4.7 \mathrm{~Hz}), 2.10(1 \mathrm{H}, \mathrm{dd}, J=13.6,4.7$ Hz), 1.99 (2H, br q, $J=7.3 \mathrm{~Hz}), 1.61-1.73(3 \mathrm{H}, \mathrm{m}), 1.34$ (1H, ddd, $J=14.2,8.8,3.8 \mathrm{~Hz}), 1.02(3 \mathrm{H}$, t, $J=7.4 \mathrm{~Hz}), 0.93(9 \mathrm{H}, \mathrm{t}, J=8.0 \mathrm{~Hz}), 0.90(9 \mathrm{H}, \mathrm{s}), 0.60(6 \mathrm{H}, \mathrm{q}, J=8.0 \mathrm{~Hz}), 0.08(3 \mathrm{H}, \mathrm{s}), 0.07(3 \mathrm{H}$, s);

${ }^{13} \mathrm{C}$ NMR (100.6 MHz, $\left.\mathrm{CDCl}_{3}\right) \delta$ 209.1, 159.2, 147.9, 130.1, 129.3, 113.7, 110.8, 74.2, 73.9, 73.0, 70.6, 67.9, 66.0, 56.4, 55.2, 50.8, 48.5, 45.4, 42.0, 41.1, 29.0, 25.9, 18.0, 12.2, 6.8, 4.9, -4.1, -4.6; IR (liquid film) 3507 (br), 1710 (s), 1612, $1514 \mathrm{~cm}^{-1}$;

HRMS (+ESI) $(m / z)[M+N a]^{+}$Calc. for $\mathrm{C}_{36} \mathrm{H}_{66} \mathrm{O}_{7} \mathrm{Si}_{2} \mathrm{Na}$ : 689.4245, found: 689.4234.

COMPETING INTERESTS STATEMENT The authors declare that they have no competing financial interests.

\section{REFERENCES}

1. Kim, B.M., Williams, S.F. \& Masamune, S. The Aldol Reaction: Group III Enolates. In Comprehensive Organic Synthesis (eds. Trost, B.M. \& Fleming, I.) 301-320 (Pergamon Press, Oxford, United Kingdom, 1991).

2. Cowden, C.J. \& Paterson, I. Asymmetric aldol reactions using boron enolates. Org. React. 51, 1-200 (1997).

3. Paterson, I., Cowden, C.J. \& Wallace, D.J. Stereoselective Aldol Reactions in the Synthesis of Polyketide Natural Products. In Modern Carbonyl Chemistry (ed. Otera, J.) 249-297 (Wiley-VCH, Weinheim, Germany, 2000).

4. Masamune, S., Choy, W., Petersen, J.S. \& Sita, L.R. Double stereodifferentiation and a new strategy for stereocontrol in organic syntheses. Angew. Chem., Int. Ed. Engl. 24, 1-30 (1985). 
5. Paton, R.S. \& Goodman, J.M. Understanding the Origins of Remote Asymmetric Induction in the Boron Aldol Reactions of $\beta$-Alkoxy Methyl Ketones. Org. Lett. 8, 4299-4302 (2006).

6. Goodman, J.M. \& Paton, R.S. Enantioselectivity in the boron aldol reactions of methyl ketones. Chem. Commun., 2124-2126 (2007).

7. Cergol, K.M., Turner, P. \& Coster, M.J. The boron-mediated ketone-ketone aldol reaction. Tetrahedron Lett. 46, 1505-1509 (2005).

8. Cergol, K.M., Jensen, P., Turner, P. \& Coster, M.J. Reversibility in the boron-mediated ketone-ketone aldol reaction. Chem. Commun., 1363-1365 (2007).

9. Brown, H.C., Dhar, R.K., Ganesan, K. \& Singaram, B. Enolboration. 1. Dicyclohexylchloroborane/triethylamine as a convenient reagent for enolboration of ketones and other carbonyl derivatives. J. Org. Chem. 57, 499-504 (1992).

10. Evans, D.A., Nelson, J.V., Vogel, E. \& Taber, T.R. Stereoselective aldol condensations via boron enolates. J. Am. Chem. Soc. 103, 3099-3111 (1981).

11. Paterson, I. \& Goodman, J.M. Aldol reactions of methyl ketones using chiral boron reagents: a reversal in aldehyde enantioface selectivity. Tetrahedron Lett. 30, 997-1000 (1989).

12. Paterson, I. et al. Enantio- and diastereoselective aldol reactions of achiral ethyl and methyl ketones with aldehydes. The use of enol diisopinocampheylborinates. Tetrahedron 46, 46634684 (1990).

13. Paterson, I. et al. The stereocontrolled total synthesis of altohyrtin A/spongistatin 1: fragment couplings, completion of the synthesis, analogue generation and biological evaluation. Org. Biomol. Chem. 3, 2431-2440 (2005).

14. Paterson, I. et al. Stereocontrolled total synthesis of (+)-altohyrtin A/spongistatin 1. Angew. Chem. Int. Ed. 40, 4055-4060 (2001).

15. Paterson, I. \& Coster, M.J. Total synthesis of altohyrtin A (spongistatin 1): an alternative synthesis of the CD-spiroacetal subunit. Tetrahedron Lett. 43, 3285-3289 (2002).

16. Paterson, I. \& Coster, M.J. Total synthesis of spongistatin 1 (altohyrtin A): a tale of ten aldols. Strategies and Tactics in Organic Synthesis 4, 211-245 (2004).

17. Paterson, I., Coster, M.J., Chen, D.Y.K., Gibson, K.R. \& Wallace, D.J. The stereocontrolled total synthesis of altohyrtin A/spongistatin 1: the CD-spiroacetal segment. Org. Biomol. Chem. 3, 2410-2419 (2005).

18. Paterson, I., Acena, J.L., Bach, J., Chen, D.Y.K. \& Coster, M.J. Synthesis and biological evaluation of spongistatin/altohyrtin analogues: E-ring dehydration and C46 side-chain truncation. Chem. Commun., 462-463 (2003).

19. Paterson, I. et al. The stereocontrolled total synthesis of altohyrtin A/spongistatin 1: the southern hemisphere EF segment. Org. Biomol. Chem. 3, 2420-2430 (2005).

20. Paterson, I. et al. The stereocontrolled total synthesis of altohyrtin A/spongistatin 1: the ABspiroacetal segment. Org. Biomol. Chem. 3, 2399-2409 (2005). 


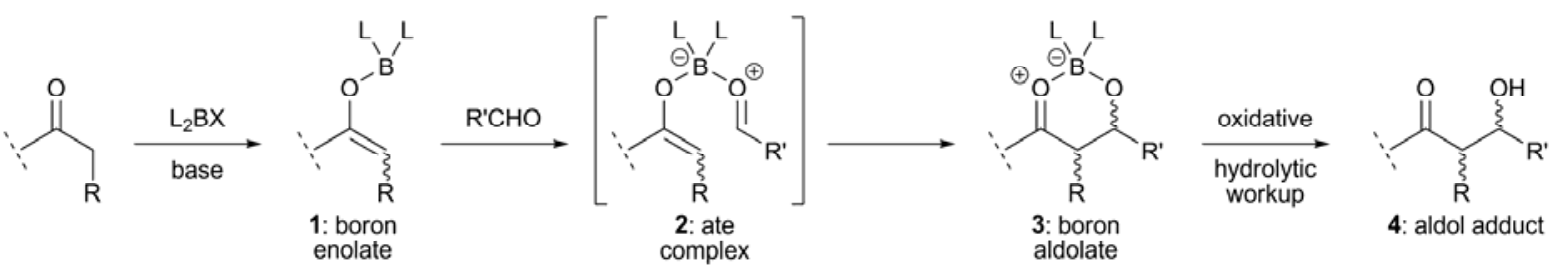

Figure 1 General scheme for the boron-mediated aldol reaction.

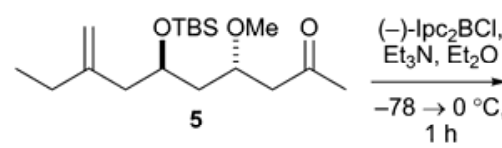

$(-)-\mathrm{Ipc}_{2} \mathrm{BCl}=$
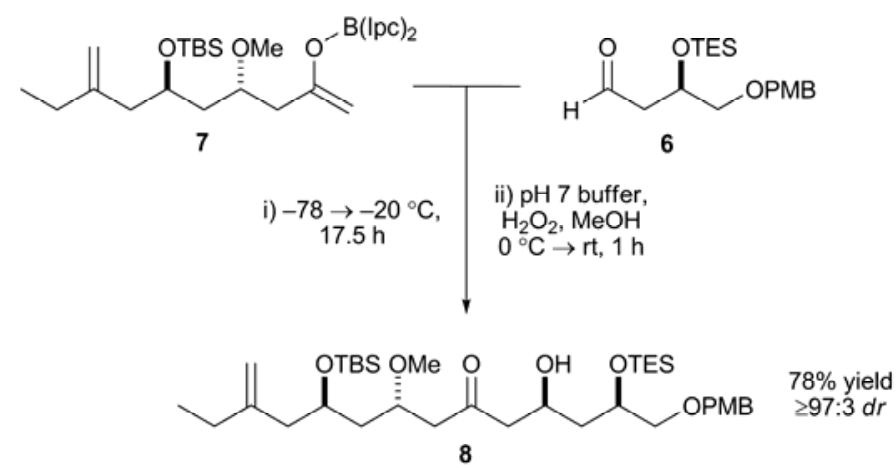

Figure 2 Asymmetric aldol reaction exploiting triple asymmetric induction.

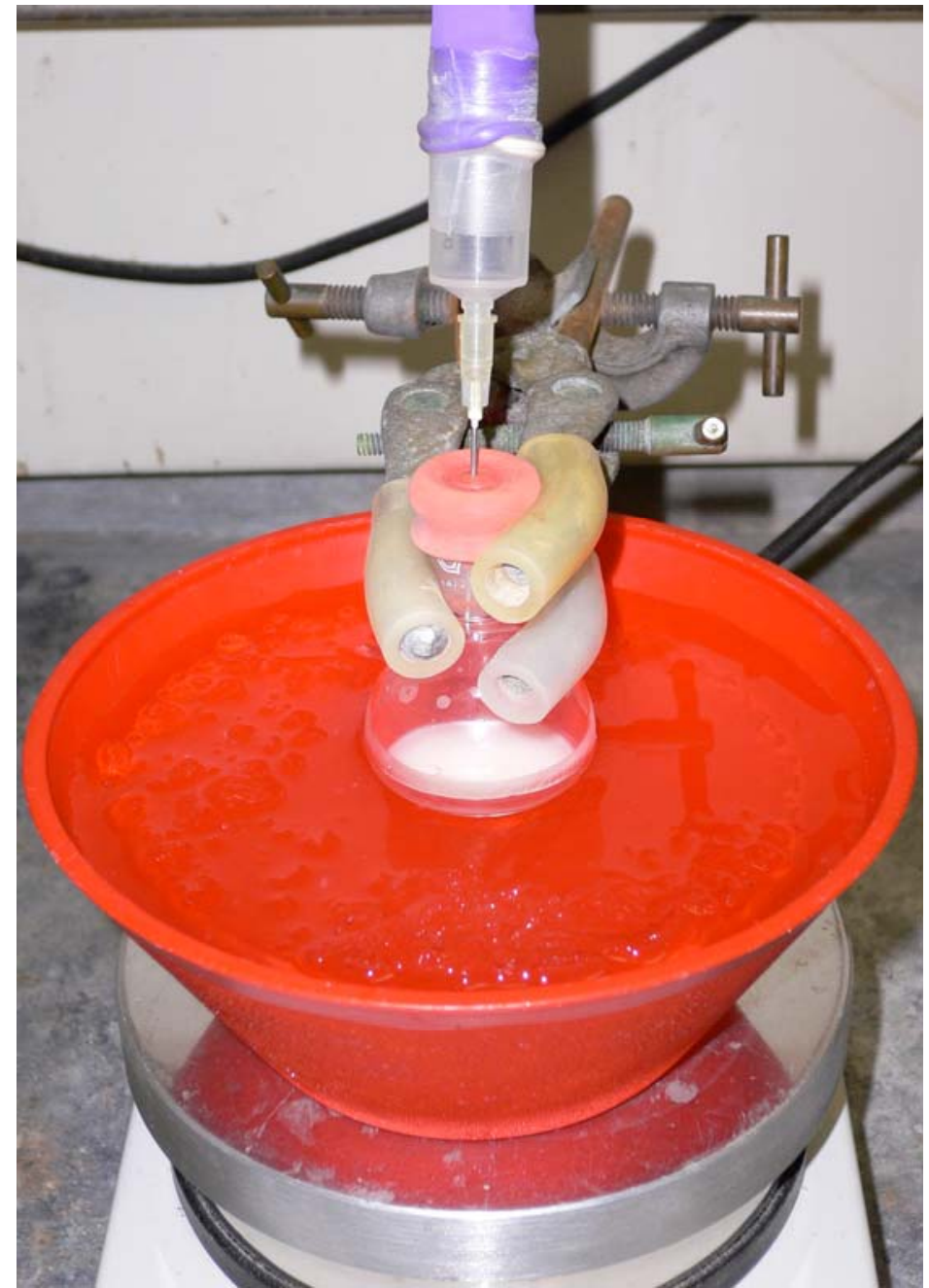

Figure 3 Boron enolate formation (end of step 15), showing precipitate of triethylamine hydrochloride. 
Figure 4 Reaction flask ready for placement in freezer at $-20{ }^{\circ} \mathrm{C}$ (end of step 22). 